\title{
HYDRAULIC PERFORMANCE OF ELASTOMERIC BONDED PERMEABLE REVETMENTS AND SUBSOIL RESPONSE TO WAVE LOADS
}

\author{
H. Oumeraci ${ }^{1}$, T. Staal ${ }^{1}$, S. Pfoertner ${ }^{1}$, M. Kudella ${ }^{2}$, S. Schimmels ${ }^{2}$, H.J. Verhagen ${ }^{3}$
}

\begin{abstract}
Elastomeric bonded permeable revetments, also called PBA (Polyurethane bonded aggregate) revetments, are highly porous structures made of mineral aggregates (e.g. crushed stones) which are durably and elastically bonded by polyurethane (PU). Despite their numerous advantages as compared to conventional revetments and the large experience available from more than 25 pilot projects, physically-based design formulae to predict their hydraulic performance, wave loading and response are still lacking. Therefore, the present study aims at improving the understanding of the processes involved in the interaction between wave, revetment and foundation, based on largescale model tests performed in the Coastal Research Centre (FZK), Hannover/Germany, and to provide prediction formulae/diagrams. This paper is focused on the prediction of the hydraulic performance (wave reflection, wave runup and run-down) and the response of the sand core (pore pressure) beneath the revetment for a wide range of wave conditions, including the analysis of an observed failure due to transient soil liquefaction.
\end{abstract}

Keywords: Bonded permeable revetments, wave reflection, wave run-up and run-down, wave-induced pore pressure, failure, transient soil liquefaction

\section{INTRODUCTION}

Open revetments as compared to impermeable smooth revetments have the advantage of substantially reducing wave run-up, and thus the required crest level of the structure. Moreover, wave reflection which may affect sea bed stability (scour) and navigation is also reduced. Bonding the mineral aggregates (e.g. crushed stones) results in a revetment of much smaller thickness to resist the design wave loads. With these and further background considerations, Polyurethane (PU) has been introduced 2004 for the shore protection of the Hamburger Hallig in Germany as a highly porous structure made of mineral aggregates with a durable and environmentally neutral bonding in a marine environment. The basic material and hydraulic properties of such an elastomeric structure have been investigated by $\mathrm{Gu}$ (2007). A tentative structural analysis and design based on several assumptions related to wave loading and resistance parameters have been conducted by Bijlsma (2008). These and further studies (Davidse, 2009) have shown that more knowledge and reliable prediction formulae are urgently needed for the hydraulic performance, the wave loads and the response of elastomeric bonded permeable revetment and its subsoil, including the most relevant failure mechanisms.

In order to improve the understanding of all relevant processes involved in the wave-structuresubsoil interaction and to come up with physically-based prediction formulae, large-scale model tests were performed 2009 in the Large Wave Flume (GWK) of the Coastal Research Centre (FZK), a joint institution of both universities Hannover and Braunschweig. The main objectives of these tests are to develop empirical/semi-empirical prediction formulae for wave reflection, wave run-up, pressure distribution on and beneath the revetment for impact and non-impact loads as well as for pore pressure distribution in the subsoil. These results and formulae will be incorporated in a design manual for polyurethane bonded aggregate revetments.

The primary objective of the paper is to provide a summary of the results related to the hydraulic performance (wave reflection, wave run-up and run-down) and to the response of the sand core beneath the revetment (pore pressures), including the analysis of the failure experienced by a tested under-designed revetment alternative.

\section{EXPERIMENTAL SET-UP AND TESTING PROGRAM}

As mentioned above, the experiments were performed in the Large Wave Flume (GWK) with a length $1=330 \mathrm{~m}$, a depth $\mathrm{d}=7 \mathrm{~m}$, and a width $\mathrm{w}=5 \mathrm{~m}$.

Three Model Alternatives A, B and C with the same slope $1: 3$ and the same thickness $\left(t_{R}=0.15 \mathrm{~m}\right)$ but with different thicknesses of the gravel under layer $\left(t_{R}=0.0 \mathrm{~m} ; 0.10 \mathrm{~m}\right.$ and $\left.0.20 \mathrm{~m}\right)$ were tested

\footnotetext{
${ }^{1}$ Leichtweiss-Institute for Hydraulic Engineering and Water Resources, Technische Universitaet Braunschweig, Beethovenstr. 51a, D-38106 Braunschweig, Germany

${ }^{2}$ Coastal Research Centre (FZK) of Leibniz University Hannover and TU Braunschweig, Merkurstr. 11, D-30419 Hannover, Germany

${ }^{3}$ Faculty of Civil Engineering and Geosciences, Delft University of Technology, The Netherlands
} 
(Fig. 1\&2). The embankment was built of sand with grain size $\mathrm{D}_{50}=0.34 \mathrm{~mm}, \mathrm{D}_{10}=0.18 \mathrm{~mm}$ and $\mathrm{U}=\mathrm{D}_{60} / \mathrm{D}_{10}=2.11$. The foreshore of the PBA revetment (slope of 1:3) is a sand bed with a slope of $1: 20$. The toe of the revetment is located $1.0 \mathrm{~m}$ above the flume bottom while the crest of the revetment is extended up to $6.70 \mathrm{~m}$ near the top edge of the flume which is at $7.00 \mathrm{~m}$ (Fig. 1).

In a first phase, the model set-up consists of two alternative revetments. The two model alternatives $\mathrm{A}$ and $\mathrm{B}$ were built together side by side, each covering half of the wave flume width $(2 \times 2.5 \mathrm{~m})$ and tested simultaneously under the same incident wave conditions (Fig 1).

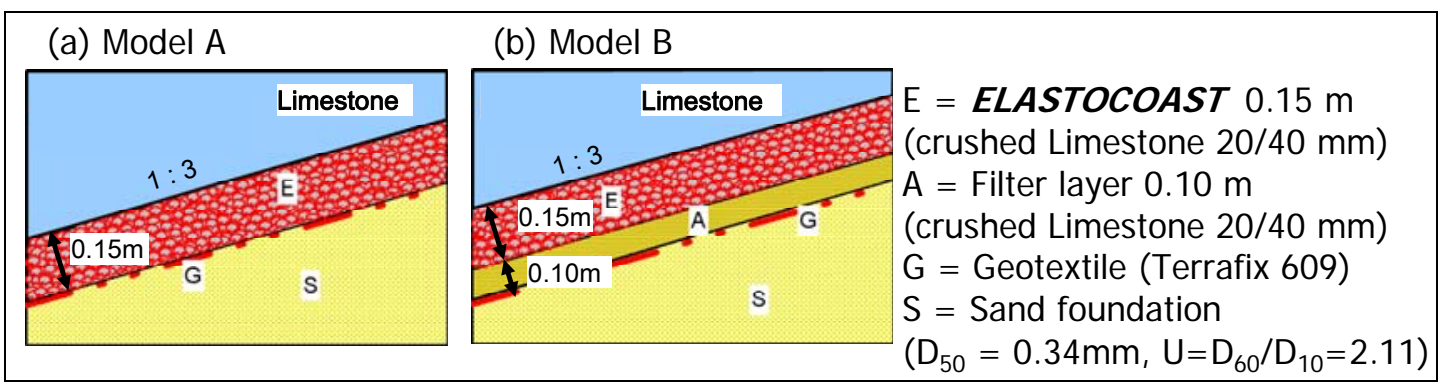

Figure 1. Model Alternatives A and B

Both model alternatives have a PBA layer of the same thickness $(\mathrm{d}=0.15 \mathrm{~m})$ made of the same crushed limestones $(20 / 40 \mathrm{~mm})$ bonded together by the same Polyurethane. The difference between the two models consists only in the layer beneath the PBA (Figure 1a,b). While for Model Alternative A the PBA lies directly on a geotextile filter, for Model Alternative B it lies on a gravel underlayer with a thickness of $0.10 \mathrm{~m}$ using the same crushed limestone material $(20 / 40 \mathrm{~mm})$ as for the PBA revetment. The gravel underlayer is inserted between the PBA layer and the geotextile filter lying on the sand slope (Figure 1.b). The two alternatives are separated by a thin wall made of water resistant plywood (Oumeraci et al, 2009b).

After the damage of Model Alternative A which was built across one half width of the flume, the damaged revetment was completely removed and replaced by a third Model Alternative C (Figure 2). This alternative is similar to Model Alternatives A and B, but the PBA layer consists of crushed granite stones $(16 / 36 \mathrm{~mm})$ and the thickness of the underlayer made of the same stones is with $0.20 \mathrm{~m}$ twice as large as in Model Alternative B (Figures 1 \&2).

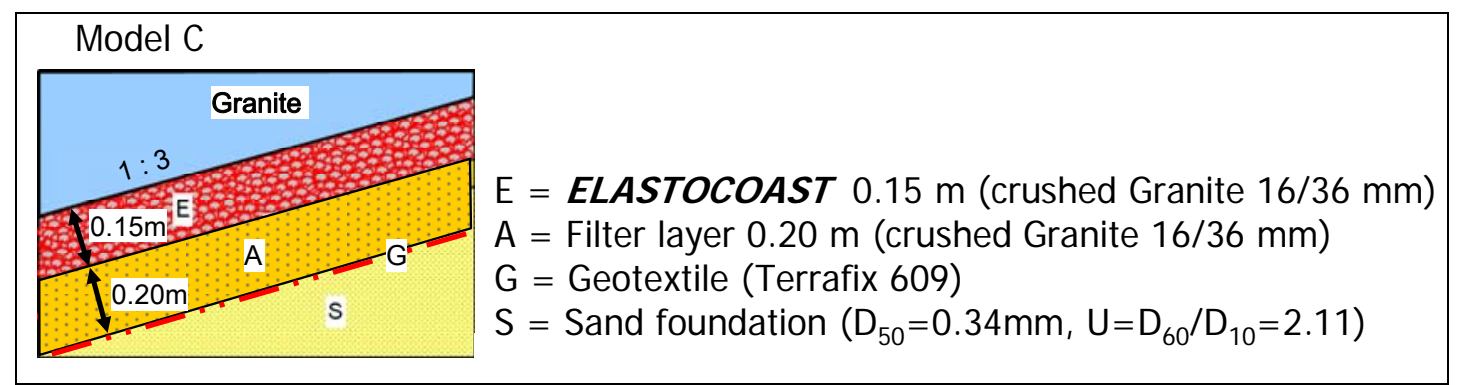

Figure 2. Model Alternative C (built after failure of Model Alternative A)

A total of 86 measuring devices synchronized with two digital video cameras were used to record the waves in the far and near field, wave run-up and run-down, run-up layer thickness and velocity, pressures on and just beneath the revetment, pore pressure in the subsoil as well as motions of the revetment normal to the slope. The types and optimal locations of these devices were determined by a preparatory study, applying available empirical formulae and numerical modeling (Oumeraci et al, 2009a).

More than 35 tests with regular waves $(\mathrm{H}=0.2-1.3 \mathrm{~m}, \mathrm{~T}=3-8 \mathrm{~s}, \mathrm{~h}=3.4 .-4.2 \mathrm{~m}, 100$ waves/test $)$ and more than 40 tests with irregular waves $\left(\mathrm{H}_{\mathrm{s}}=0.2-1.1 \mathrm{~m}, \mathrm{~T}_{\mathrm{p}}=3-8 \mathrm{~s}, \mathrm{~h}=3.4-4.2 \mathrm{~m}, 1000\right.$ waves/test) were performed, including few tests with solitary waves and "wave focussing". Since the main goal of the study is to come up with empirical formulae/diagrams for design purposes, the main focus was put on the analysis of the experiments with wave spectra. Therefore, the results and formulae described in this paper are mainly based on the irregular wave tests (For comparison with regular wave tests see Oumeraci et al, 2009b). 


\section{HYDRAULIC PERFORMANCE}

Wave reflection from coastal structures may severely affect the structure stability by increasing sea bed scour. It may also increase the erosion of the foreshore and of the neighbouring coastal stretches. Reflection coefficient $C_{r}$, obtained from the analysis of the tests, ranges from $C_{r}=0.26$ to $C_{r}=0.75$.

Several prediction formulae for the reflection coefficient have been proposed in the past (Zanuttigh \& Van der Meer, 2006). A comparative analysis of the uncertainties associated with 12 prediction formulae was performed previously by Oumeraci \& Muttray (2001), showing coefficients of variation from 10 to $140 \%$. Amongst the existing models, the basic fitting formula by Seelig (1983) shown in Fig. 3 was found to be most widely used and is associated with the lowest uncertainties. Plotting reflection coefficient $\mathrm{C}_{\mathrm{r}}$ against surf similarity parameter $\xi_{\mathrm{m}-1,0}$, calculated using characteristic wave period $\mathrm{T}_{\mathrm{m}-1,0}$ and characteristic wave height $\mathrm{Hm} 0$ the result in Fig 3 is obtained.

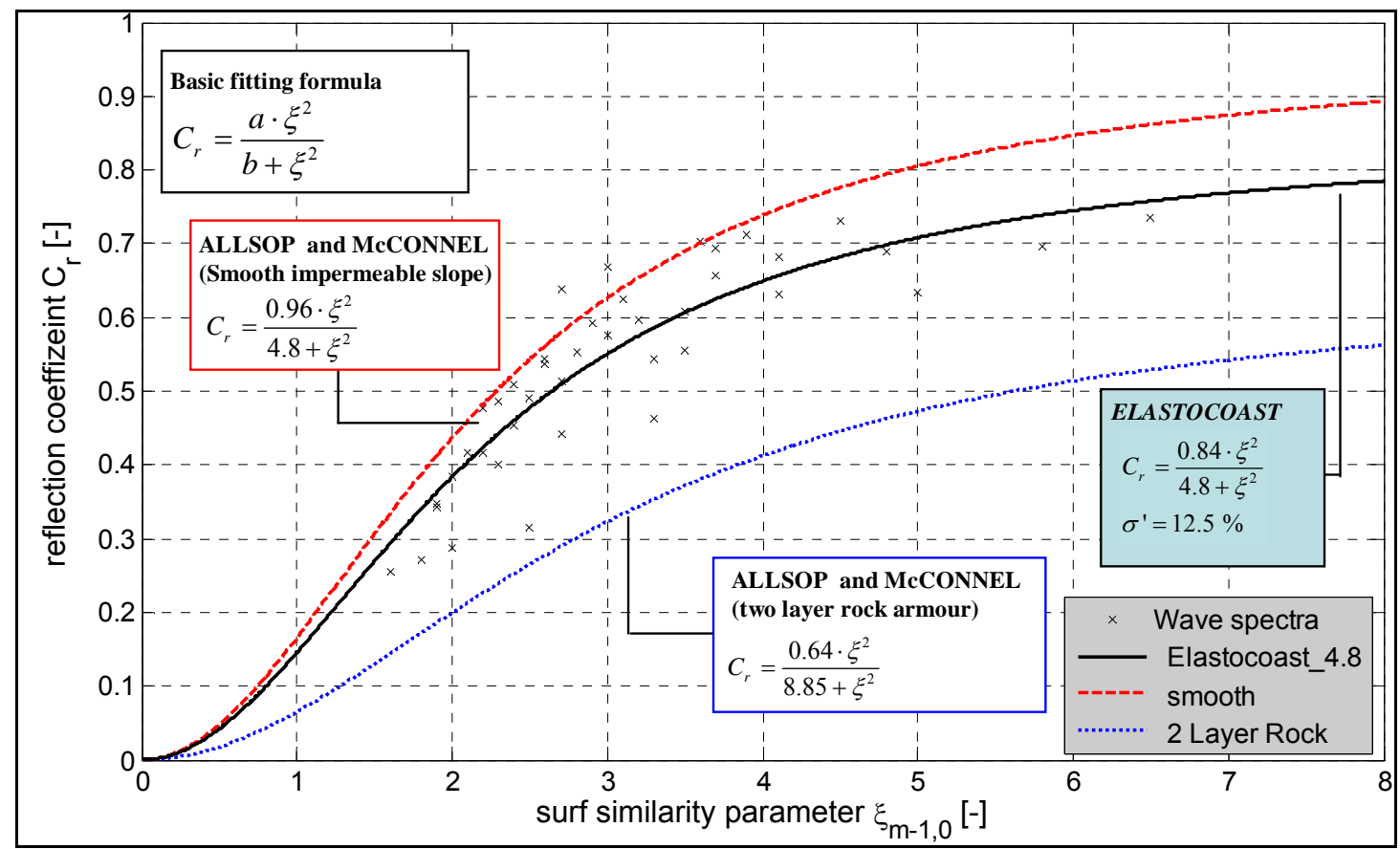

Figure 3. Reflection coefficient $C_{r}$ plotted against surf similarity parameter $\xi_{m-1,0}$

The reflection coefficient of the PBA revetment remains smaller than that of a smooth impermeable slope. For a two-layer rock armour it is much smaller than the reflection coefficient for the PBA revetment. Hence, reflection coefficient $\mathrm{C}_{\mathrm{r}}$ for the PBA revetment investigated in this study can be estimated with Eq. (1), associated with a coefficient of variation $\sigma^{\prime}=12.5 \%$ :

$$
\mathrm{C}_{\mathrm{r}}=\frac{0.84 \cdot \xi^{2}}{4.8+\xi^{2}}
$$

Wave run-up $\mathrm{R}_{\mathrm{u}}$ : Generally, the run-up level exceeded by $2 \%$ of the incident waves $\left(\mathrm{R}_{\mathrm{u} 2 \%}\right)$ is commonly used for design purpose. $\mathrm{R}_{\mathrm{u} 2 \%}$ generally depends on the wave height, the surf similarity parameter, the geometry and surface roughness of the slope, and on the permeability of the structure. For porous structures with a rough slope such as PBA revetments, most of the energy dissipation takes place on and within the revetment. A literature study has shown that the run-up model for the PBA revetment for which the best fit is obtained with the measured data is the one proposed by the EurOtop manual for smooth impermeable slopes (Eurotop, 2007). Based on this model, run-up formulae were determined for the PBA revetment with a coefficient of variation $\sigma^{\prime}$ of about $16 \%$ (Fig. 4 ): 


$$
\frac{\mathrm{R}_{\mathrm{u} 2 \%}}{\mathrm{H}_{\mathrm{m} 0}}=0.54 \cdot\left[1.65 \cdot \xi_{\mathrm{m}-1,0}\right] \text { for } \xi<2.7
$$

with a maximum of

$$
\frac{\mathrm{R}_{\mathrm{u} 2 \%}}{\mathrm{H}_{\mathrm{m} 0}}=0.77 \cdot\left[4.0-\frac{1.5}{\sqrt{\xi_{\mathrm{m}-1,0}}}\right] \text { for } \xi \geq 2.7
$$

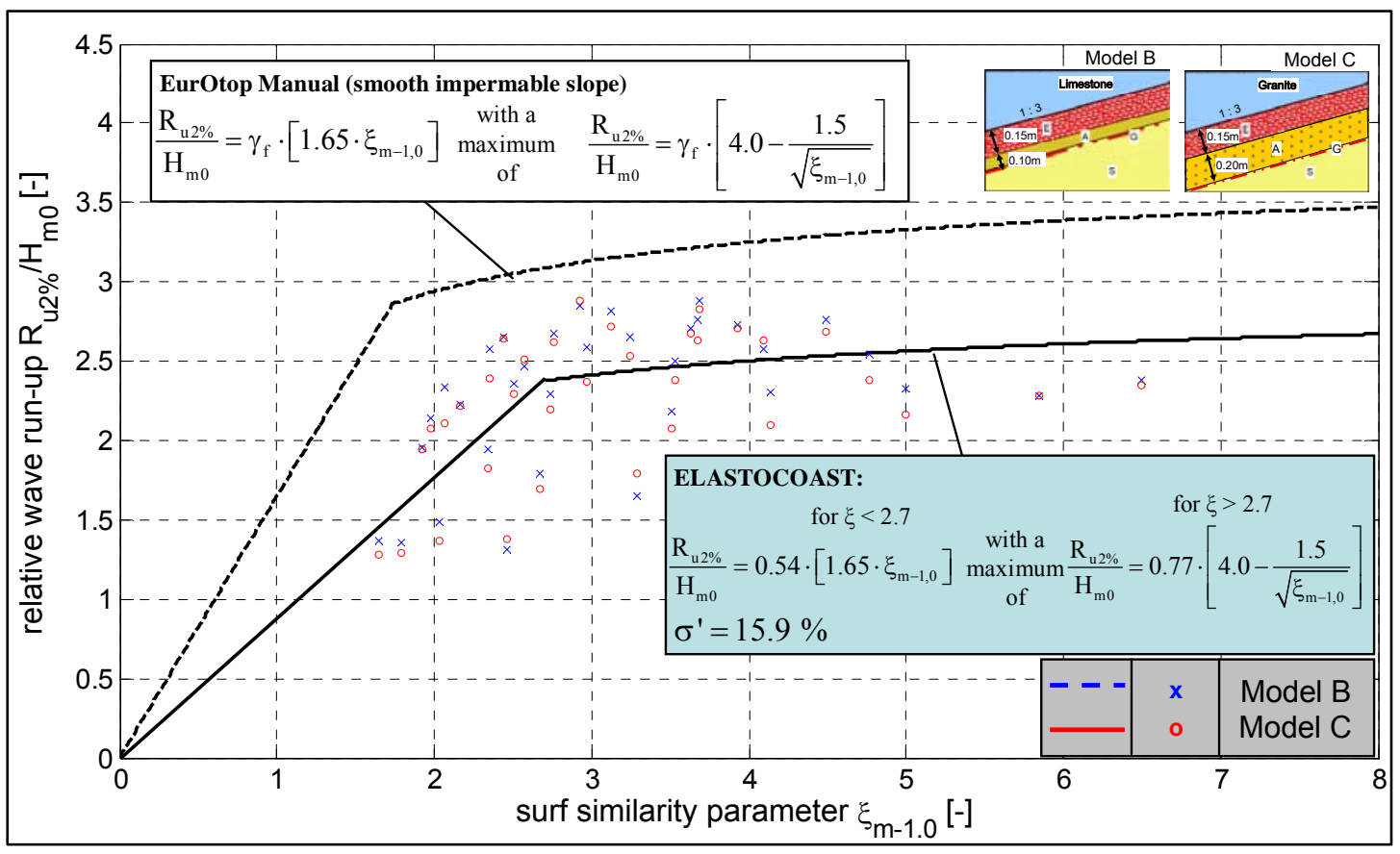

Figure 4. Wave run-up $R_{\mathrm{u} 2 \%}$ for irregular waves

Wave run-down $R_{d}$ is defined as the lowest elevation from still water level (SWL) that can be reached by the down rushing wave on the seaward face of the revetment. $R_{d}$ is important in defining the required elevation of the revetment under SWL. Run down is also important for the uplift pressure on the revetment which results from the internal water level which is generally higher than the external water level during the down rush process. The run-down level exceeded by $2 \%$ of the incident waves $\left(\mathrm{R}_{\mathrm{d} 2 \%}\right)$ is commonly used for design purpose. $\mathrm{R}_{\mathrm{d} 2 \%}$ generally depends on the wave height, the surf similarity parameter, the geometry and surface roughness of the slope, and on the permeability of the structure. A literature study has shown that the run-down models for the PBA revetment for which the best fit is obtained with the measured data are (i) those proposed by CEM- Part VI (USACE, 2002) for a smooth revetment of placed concrete blocks and (ii) the model developed for smooth impermeable slopes (Pilarczyk et al., 1995). Based on these models, the following run-down formula was determined for the PBA revetment (Fig. 5):

$$
\frac{\mathrm{R}_{\mathrm{d} 2 \%}}{\mathrm{H}_{\mathrm{m} 0}}=-0.42 \cdot \xi_{\mathrm{m}-1.0}+0.17 \text { for } \xi_{\mathrm{m}-1.0}<5.7
$$

with a maximum of 


$$
\frac{\mathrm{R}_{\mathrm{d} 2 \%}}{\mathrm{H}_{\mathrm{m} 0}}=-2.25 \text { for } \xi_{\mathrm{m}-1.0} \geq 5.7
$$

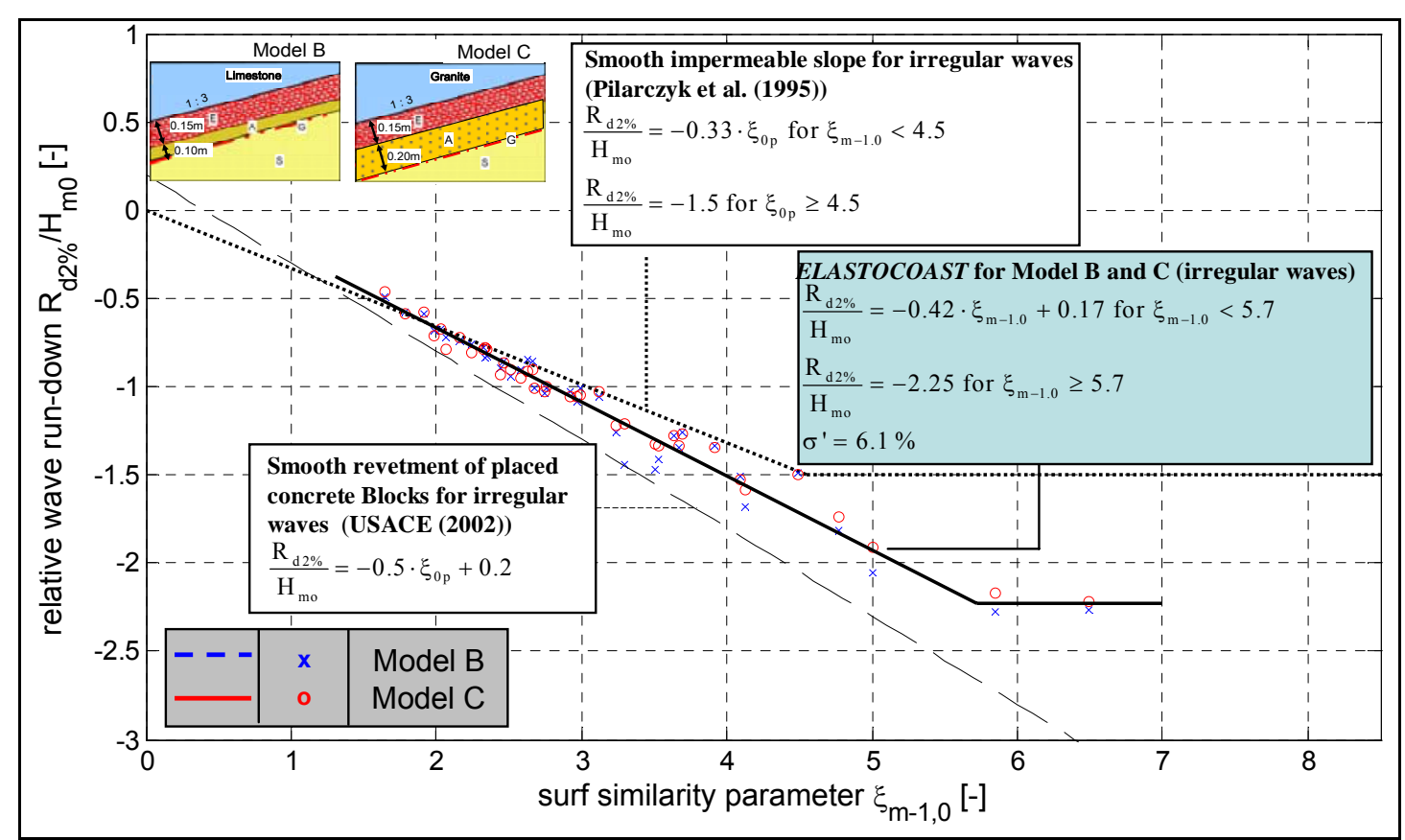

Figure 5. Wave run-down $\mathbf{R}_{\mathrm{d} 2 \%}$ for irregular waves

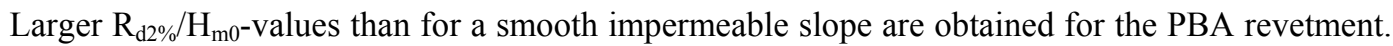
The difference is significant (up to $66 \%$ ) for large $\xi_{\mathrm{m}-1,0}$-values $\left(\xi_{\mathrm{m}-1,0}>6\right.$ ). However, smaller run-down values than for a smooth revetment of placed concrete blocks as reported in CEM (USACE, 2002) are obtained (Fig. 5).

\section{WAVE-INDUCED PORE PRESSURE IN SAND CORE BENEATH REVETMENT}

In addition to the wave pressure on and just beneath the revetment measured at PT layers 1 and 2, respectively, pore pressure induced in the sand core beneath the revetment were also measured at PT layers 3, 4 and 5 and different locations $\mathrm{B}, \mathrm{C}$ and $\mathrm{D}$, as exemplarily shown for revetment Model Alternative A in Fig. 6 .

The analysis of the wave-induced pore pressure in the sand core beneath the revetment represents an important part of the study, including both transient and residual pore pressure. Since the former were found more critical for the stability of the sand core beneath the revetment, only the results for transient pore pressure are addressed below. For more detailed and further results refer to Oumeraci et al (2009b). 


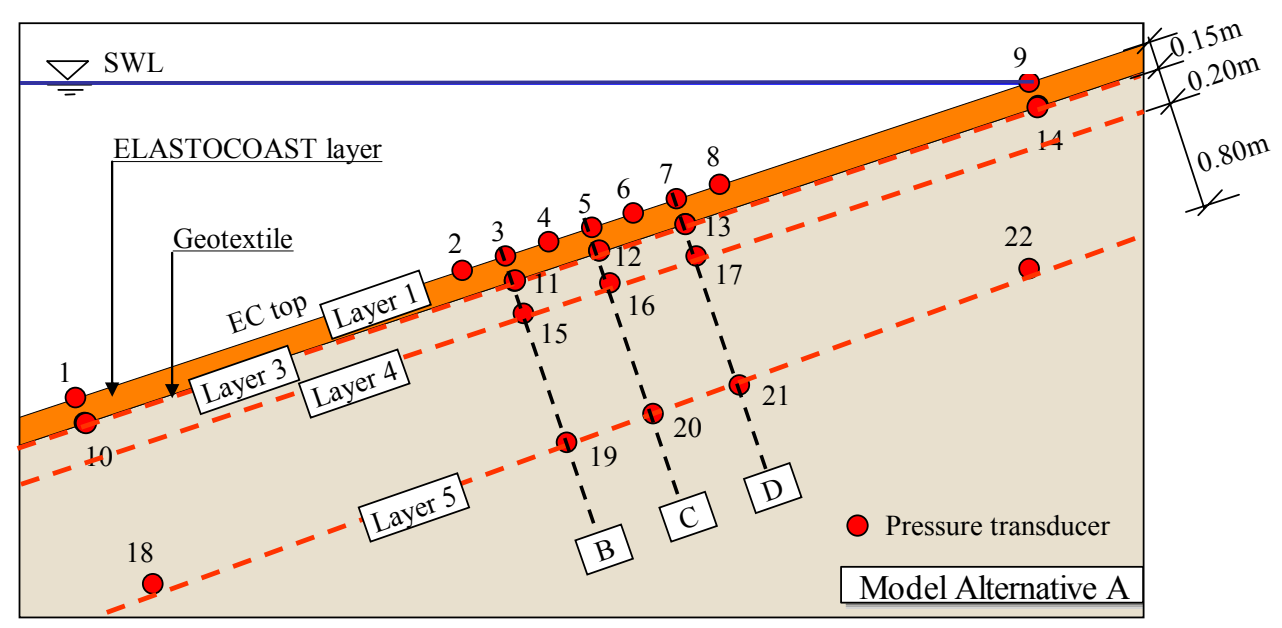

(a) Pressure transducers in layers 1-5 and locations B,C and D for Model A (without gravel filter)

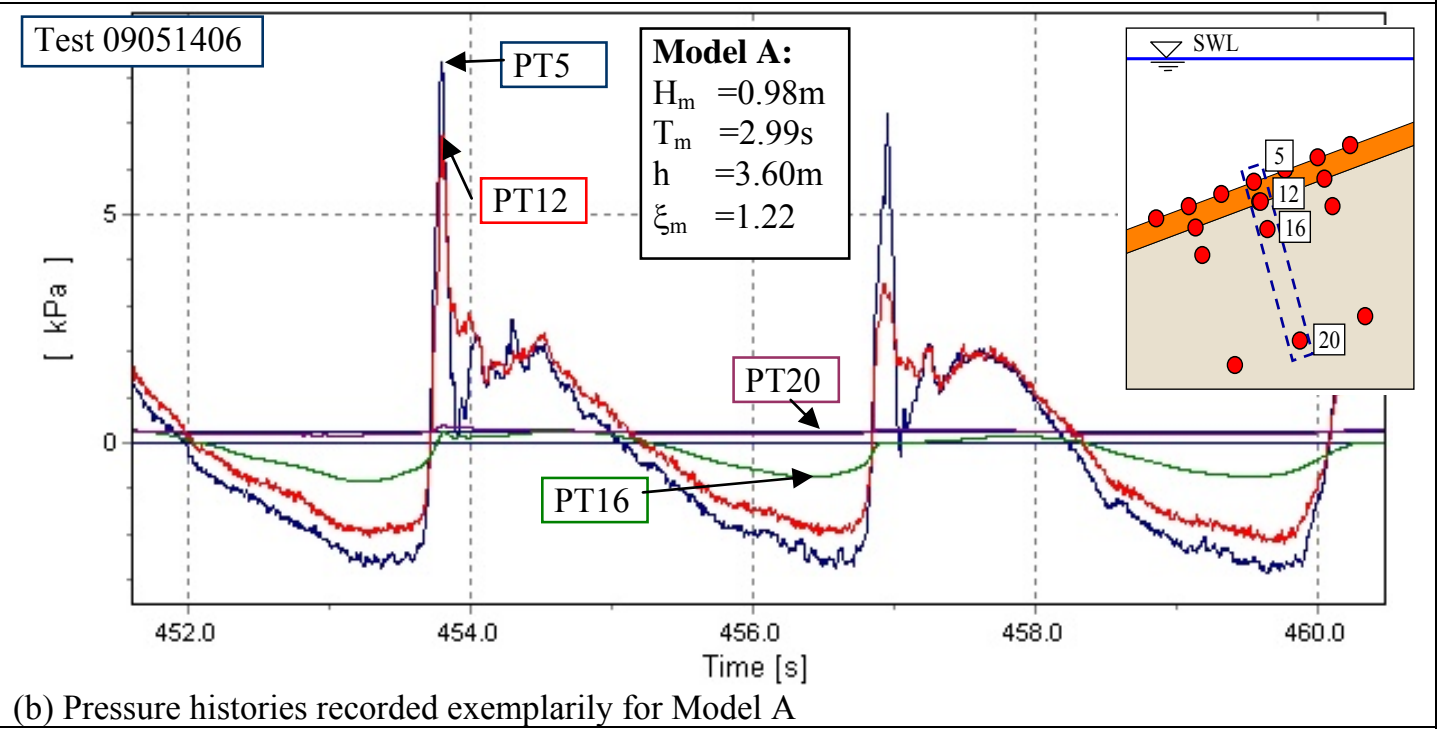

Figure 6. Pore pressure induced beneath the revetment (exemplarily for Model A)

For the prediction of the transient pore pressure, the focus was first put on the development of formulae to calculate the initial pressure $\mathrm{p}_{3 \max }$ at the upper boundary of the sand core beneath the revetment (PT Layer 3 in Fig. 6a). This is important because $p_{3 \max }$ represents the reference pore pressure to which the damped pore pressures occurring at deeper layers are related. Surprisingly, no impact pressure component is transmitted as such into the sand core, so that all pore pressure recorded in the sand core have rather quasi-static characteristics, irrespective of the type of wave load taking place on the revetment. This made the derivation of prediction formulae for the maximum pore pressure at layer $3\left(\mathrm{p}_{3 \max }\right)$ and deeper layers $4-5\left(\mathrm{p}_{4 \max }\right.$ and $\left.\mathrm{p}_{5 \max }\right)$ much easier. In fact, these could be directly derived by introducing for each layer a corresponding damping factor for the maximum pressure $\mathrm{p}_{\text {stat }}$ on the revetment.

The distribution of the pore pressure in deeper layers is based on the initial pressure $\mathrm{p}_{3 \max }$ at the upper boundary of the sand core beneath the revetment (Layer 3) which is used as a reference value $p_{0}$ $\left(=\mathrm{p}_{3 \max }\right)$. This distribution was analysed at three planes $\mathrm{B}, \mathrm{C}$ and $\mathrm{D}$ normal to the slope, showing that the damping effect is similar for all planes $\mathrm{B}, \mathrm{C}$, and $\mathrm{D}$, and that the damping rate significantly depends on initial pressure $\mathrm{p}_{0}$ (see Fig. 6 and 7 and Oumeraci et al 2009b).

The obtained prediction formulae for the maximum pore pressure at PT layers 3, 4 and 5 in the sand core are summarized in Fig. 7, also including the equation for peak pressure $p_{\text {stat }}$ on the revetment. These formulae show that the pore pressure is almost completely damped at a depth of about $80 \mathrm{~cm}$ in the sand core beneath the revetment. 


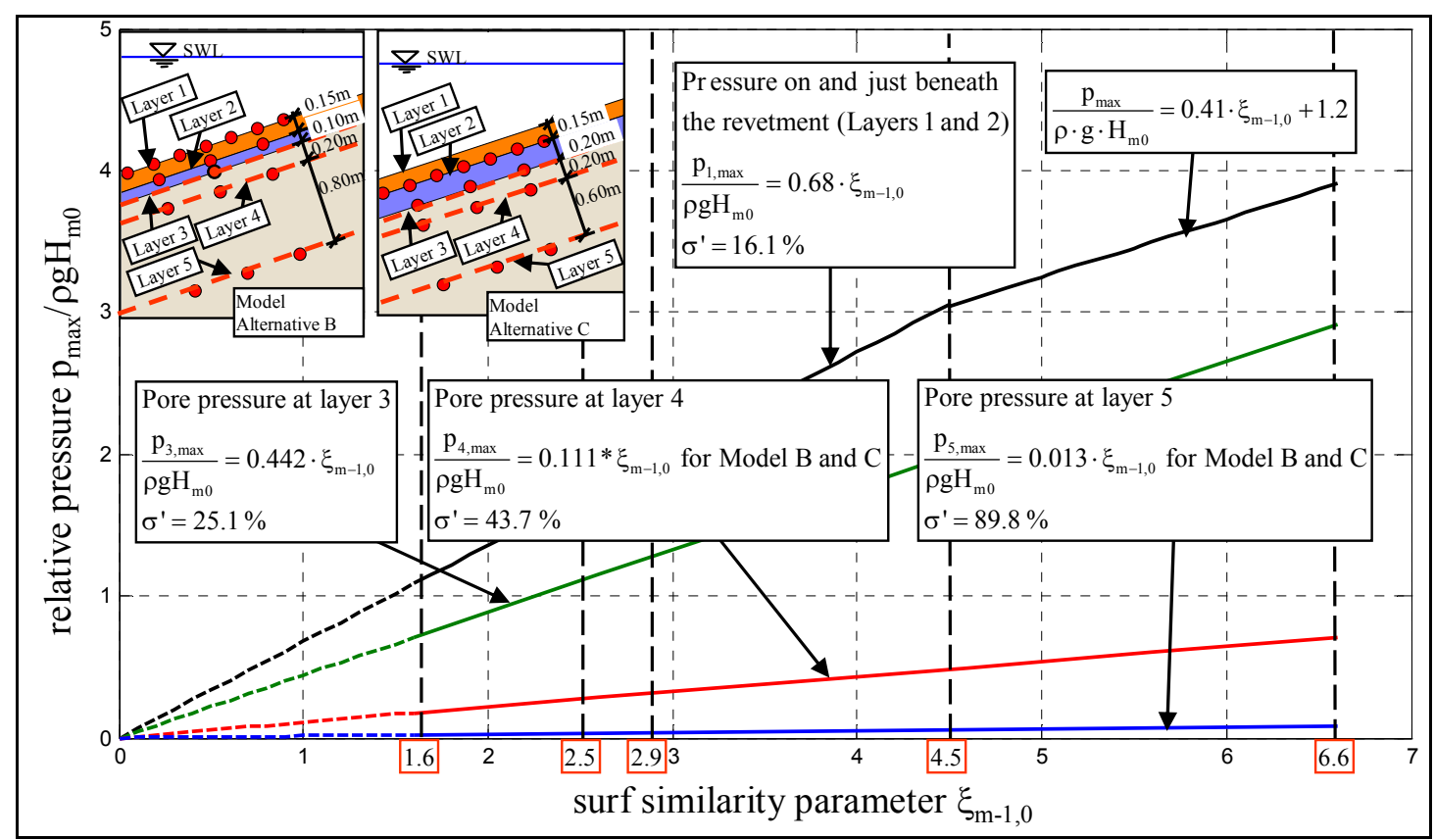

Figure 7. Proposed formulae for the damping of wave induced peak pressure at different layers beneath the revetment as a function of surf similarity parameter $\xi_{m-1,0}$

\section{FAILURE OF UNDER-DESIGNED REVETMENT MODEL A}

Description of the failure: The failure of revetment model A (Fig. 1a) occurred under regular wave attack with $\mathrm{H}=1.3 \mathrm{~m}$ and $\mathrm{T}=5 \mathrm{~s}$ for a water depth of $\mathrm{h}=3.90 \mathrm{~m}$, while for the simultaneously tested Model B (Fig. 1b) under exactly the same wave conditions no failure occurred. In a previous test with the same water depth $(\mathrm{h}=3.90 \mathrm{~m})$, the same wave height $(\mathrm{H}=1.3 \mathrm{~m})$, but with a shorter wave period $(\mathrm{T}=4 \mathrm{~s})$, no apparent damage occurred for Models A and B. Therefore, this section aims at briefly describing the observed damage of Model A as shown in Fig. 8 and at providing a possible physical interpretation of the experienced failure which is based on video observations and on the analysis of the recorded data related to the wave-induced pressure and the associated displacement of the revetment.

The exact time at which the collapse of Model A occurred is identified by means of the records of the displacement meter as illustrated by Fig.9, showing comparatively the recorded displacement for Model A and Model B. It is seen that the collapse of Model A started after $t=450 \mathrm{~s}(\mathrm{t}=7: 30 \mathrm{~min})$, i.e. between the 74th and the 75th wave of Test 09051802 .

In fact, the failure initiation started just after $\mathrm{t}=430 \mathrm{~s}(\mathrm{t}=7: 10 \mathrm{~min})$, i.e. just after the 70th wave, where a residual upward displacement started to build up for each cycle until the collapse occurred. The uplift of the revetment by each wave cycle causes a gap beneath the revetment, thus allowing the sediment to move more freely. As a result, the residual upward displacement increases progressively until the collapse occurs. The maximum residual upward displacement $(15 \mathrm{~mm})$ was recorded by the displacement meter during the run down of the 75th wave which caused the collapse of the revetment. As observed visually during the tests, the collapse occurred within a very short time interval (few seconds) without any visually perceptible precursors. Following the significant upward motion of the revetment and the resulting gaps beneath the revetment, a considerable amount of sand was washed out by the receding waves on the slope (down rush flow). As a result, a significant settlement of the revetment and a subsequent breakage of the revetment occurred. As shown in Fig. 8a, the washed sand was deposited at the toe of the revetment. This figure together with Fig. $8 \mathrm{~b}$ shows that the occurrence of the collapse was spatially concentrated just below still water level. Comparatively, no build up of the residual displacement (Fig. 9) and no damage (Fig. 8) occurred for Model B which was subject to the same incident waves as Model A. 


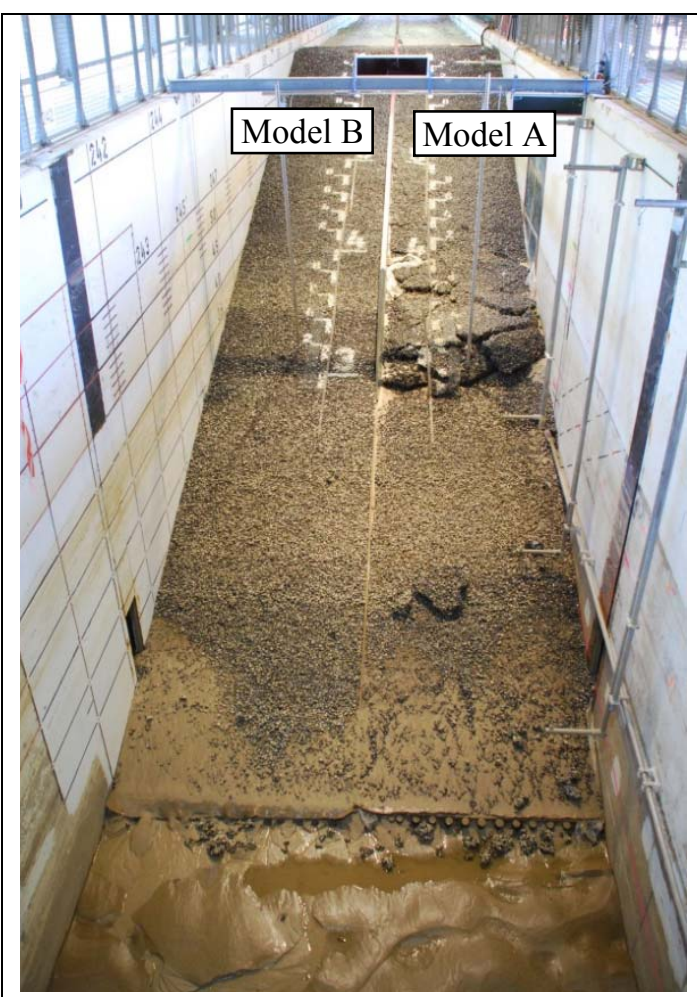

(a) Overall view

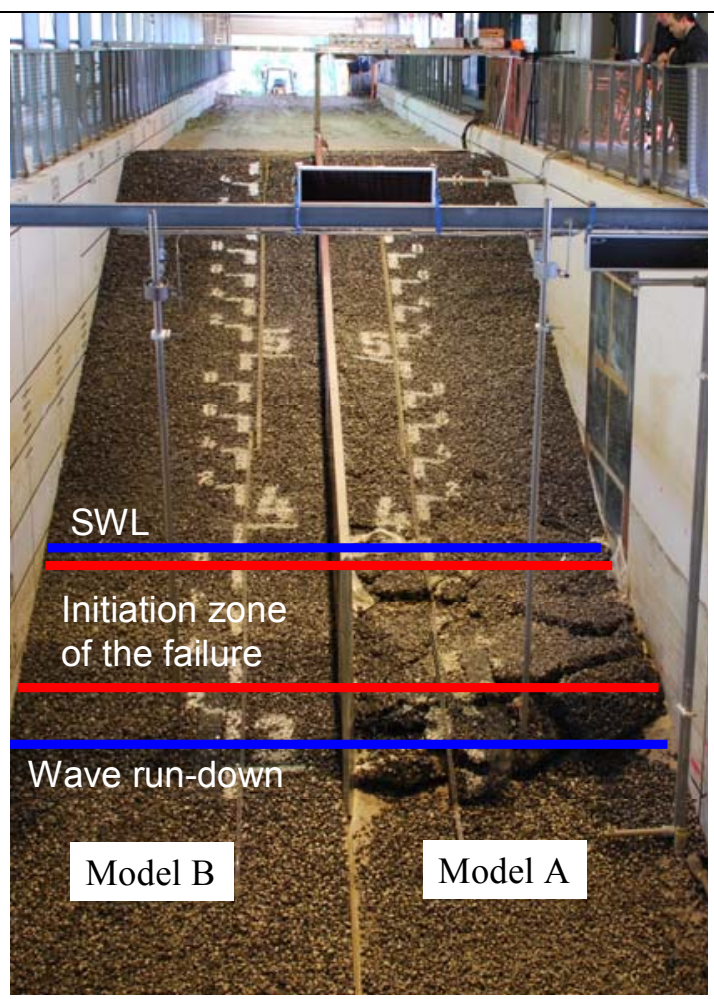

(b) Detailed view

Figure 8. Extent of damage for revetment Model $A$ after regular wave test 09051802 with $H=1.3 \mathrm{~m}, T=5.0 \mathrm{~s}$ and $\mathrm{h}=3.9 \mathrm{~m}$

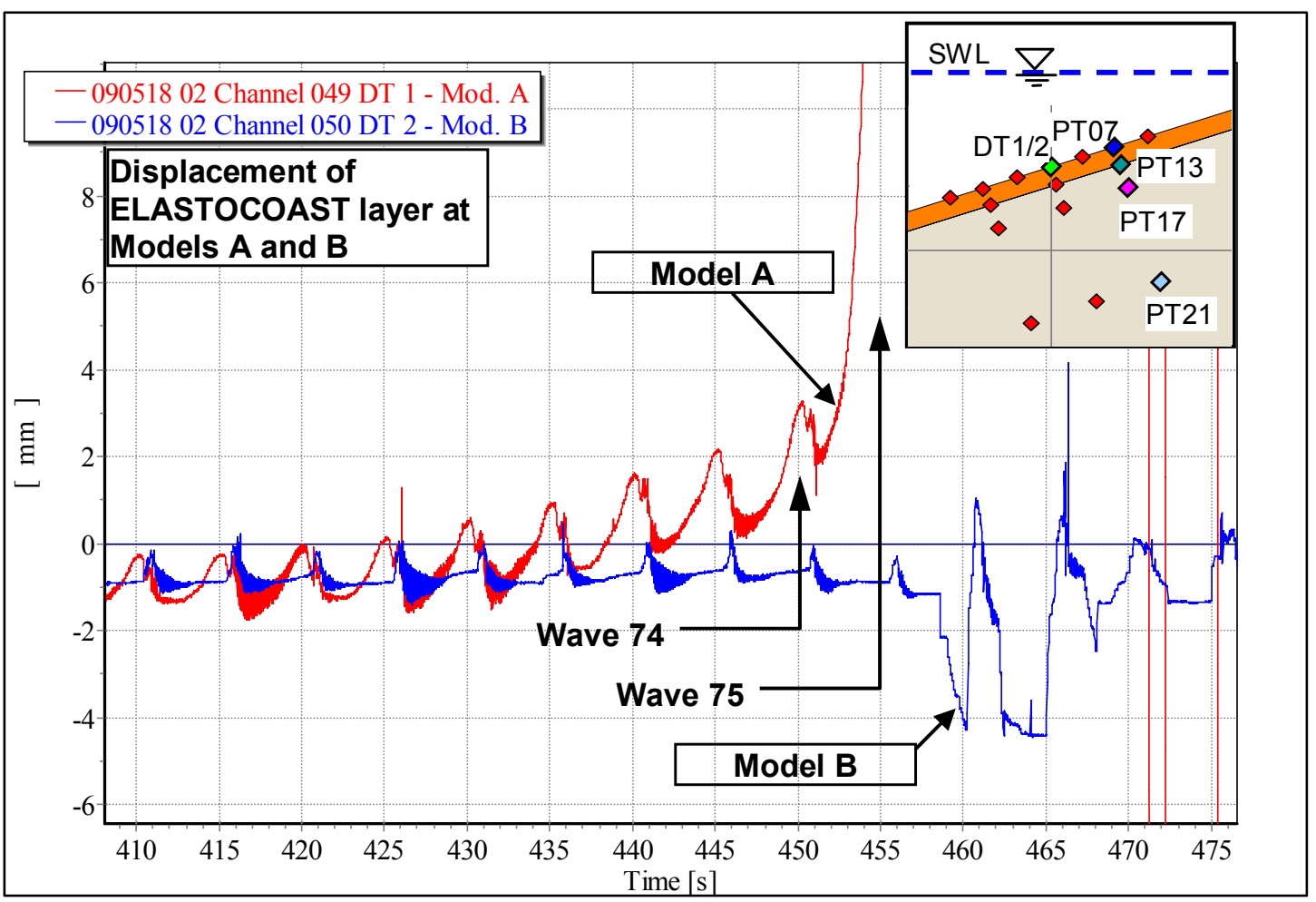

Figure 9. Displacement signals for Models A and B at the time of failure of Model A 
Following the wash out of sand and the subsequent settlement, the revetment experienced an unexpected breakage in several smaller and larger block units, leading to very large gaps through the revetment. This unexpected breakage behaviour is certainly due to the use of limestones, since the observed failure planes are generally through the limestones and not through the polyurethane binding material.

Physical interpretation of the failure: The primary difference between Model A which failed and Model B which did not fail under the same wave conditions is the $10 \mathrm{~cm}$ thick gravel underlayer (compare Figures $2 \mathrm{a}$ and $2 \mathrm{~b}$ ) which provides an additional weight and stiffness for Model B to resist against soil failure (e.g. reduction of shear resistance and soil liquefaction) of the sand core beneath the revetment which is subject to different pore pressures in both Models A and B.

The wave pressure on and beneath the revetment are almost similar for both Models A and B with the uplift pressure being slightly higher for Model A than for Model B (Oumeraci et al, 2009a,b). However, the response of the sand core beneath the revetment is different for Model A and Model B. The "negative" pore pressure amplitudes measured in $20 \mathrm{~cm}$ beneath the upper boundary of the sand core by pressure transducer PT17 on Model A and by PT43 in Model B significantly differ, while the "positive" pore pressure amplitudes are in the same range for both models A and B. In fact, the "negative" pore pressure amplitudes are almost twice for Model A than for Model B. The extremely higher "negative" pressure gradient beneath Model A induced a significantly stronger upward water flow in the sand core beneath the revetment as compared to Model B. It should be stressed that this is valid for the pore pressure signals recorded long before the failure of Model A occurred and that about 10 waves before the collapse at $\mathrm{t}=455 \mathrm{~s}$ the pore pressure amplitudes remained almost constant over time. This is surprisingly not the case for the last 10 waves before the failure occurred. As shown in Figure 10, the "negative" pore pressure amplitudes at PT17 for Model A progressively increases from $-2.4 \mathrm{kPa}$ at $\mathrm{t}=410 \mathrm{~s}$ to $-3.2 \mathrm{kPa}$ at $\mathrm{t}=445 \mathrm{~s}$, i.e. just before incipience of the failure, while the "positive" pore pressure amplitudes remained almost constant over time. As the failure started $\left(74^{\text {th }}\right.$ wave at $\mathrm{t}=$ $450 \mathrm{~s})$, the pore pressure decreased to $-5.6 \mathrm{kPa}$ and dropped to $-11.4 \mathrm{kPa}$ as the revetment collapsed $\left(75^{\text {th }}\right.$ wave at $\left.\mathrm{t}=455 \mathrm{~s}\right)$.

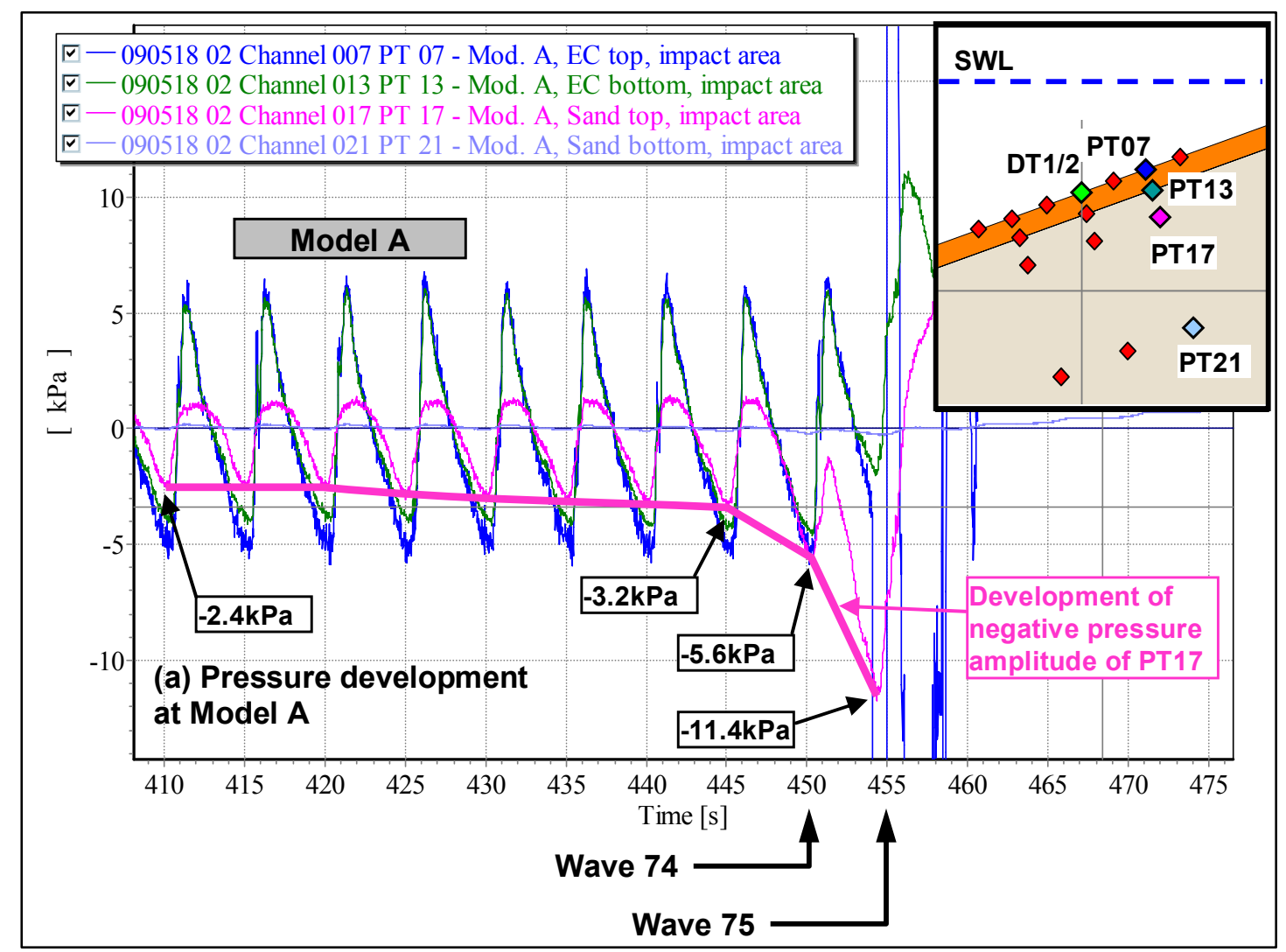

Figure 10. Pore pressure development in the sand core beneath the revetment of Model A just before collapse 
As shown by the simultaneously measured displacement of the revetment, the progressive increase in "negative" pore pressure amplitude is accompanied by a simultaneously progressive increase of the upward displacement of the revetment up to the time where the displacement meter collapsed.

These results indicate that the failure of Model A is most probably caused by the transient liquefaction of the sand core beneath the revetment. To confirm this result, a comparative stability analysis of Models A and B for the same tests at which the failure of Model A occurred is provided below.

Stability analysis of sand core beneath the revetment against soil liquefaction: Though residual pore pressure in coarser sand is relatively rare or not significant under wave action alone, both residual pore pressure $u_{r}$ and transient pore pressure $u_{t}$ should be considered for the loading term $\left(\left(\mathrm{u}_{0}-\mathrm{u}_{\mathrm{t}}\right)+\mathrm{u}_{\mathrm{r}}\right)$ in the stability analysis against soil liquefaction at each depth $\mathrm{z}^{\prime}$ in the sand core beneath the revetment can be performed as schematically illustrated in Fig. 11. The resistance term (initial effective stress $\left.\sigma_{\mathrm{v} 0}^{\prime}\right)$ is provided by the submerged weight of the soil $\left(\sigma_{\mathrm{v} 0}^{\prime}\right)_{\mathrm{s}}$ and that of the revetment $\left(\sigma_{\mathrm{v} 0}^{\prime}\right)_{\mathrm{r}}$ at the corresponding depth $\mathrm{z}$ ' beneath the surface of the sand core. If the loading term $\left(\left(\mathrm{u}_{0}-\mathrm{u}_{\mathrm{t}}\right)+\right.$ $\mathrm{u}_{\mathrm{r}}$ ) at a certain location $\mathrm{z}^{\prime}$ in the sand core reaches the effective stress $\sigma^{\prime}{ }_{\text {vo }}$, soil liquefaction will occur at that location (Fig. 11). Following this procedure, the results of the stability analysis for Model A (Test 09051802) are given in Fig. 12a, showing that transient liquefaction indeed occurred around PT Layer 4 for $\mathrm{H}=1.4 \mathrm{~m}, \mathrm{~T}=5 \mathrm{~s}$ and $\mathrm{h}=3,9 \mathrm{~m}$.

A comparison with the stability analysis of Model B for the same regular wave test (Fig. 12b) illustrates why Model B did not fail. In fact, the effective stress $\sigma^{6}$ around PT Layer 4 dropped to a very low level $\left(\sigma^{6}=0.43 \mathrm{kN} / \mathrm{m}^{2}\right)$ which is not far from the failure level.

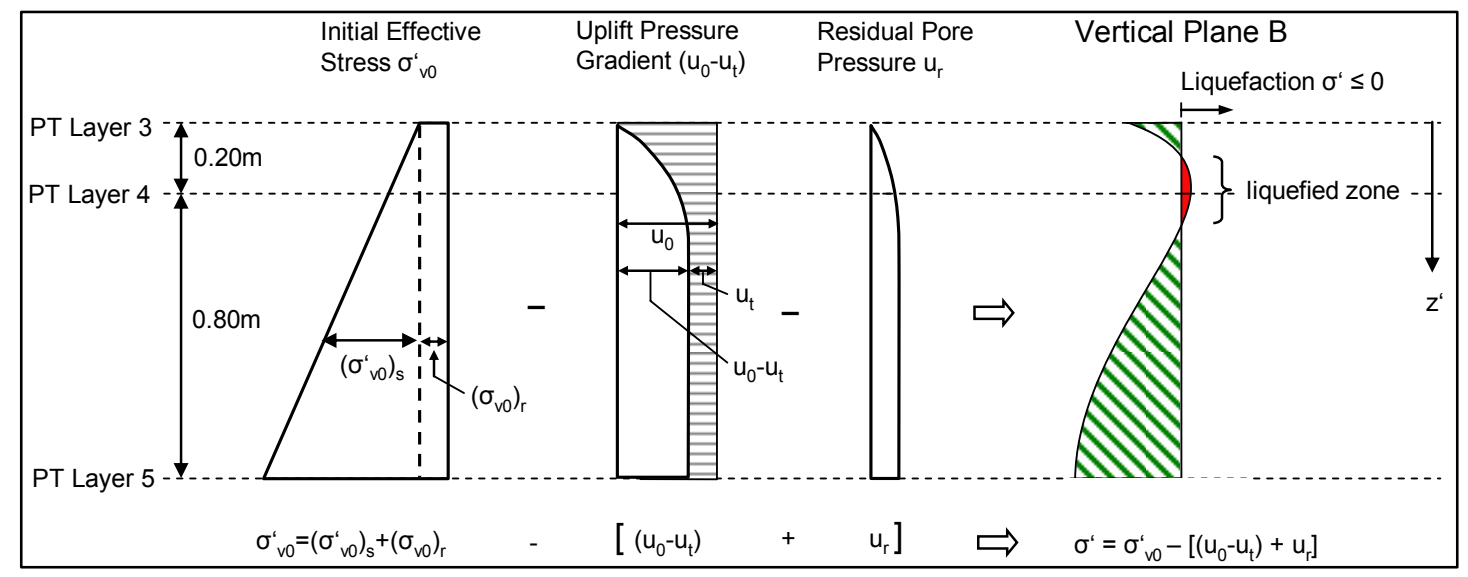

Figure 11. Stability analysis against soil liquefaction beneath the revetment (principle sketch) 


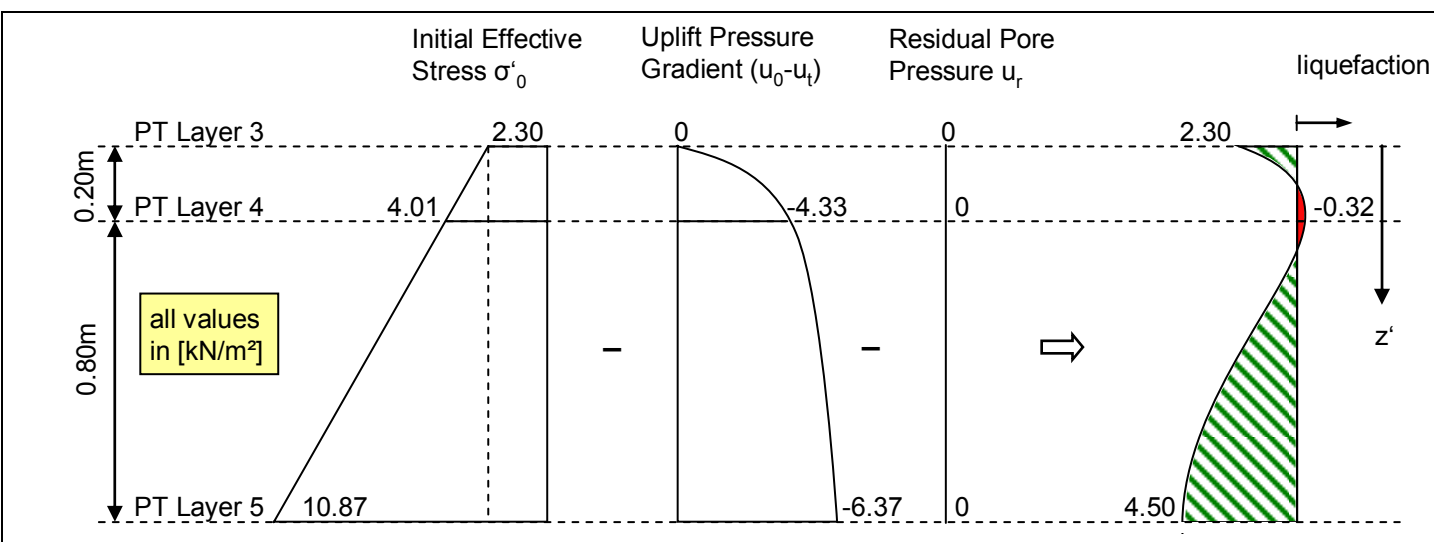

(a) Failure of Model A due to transient soil liquefaction at location B

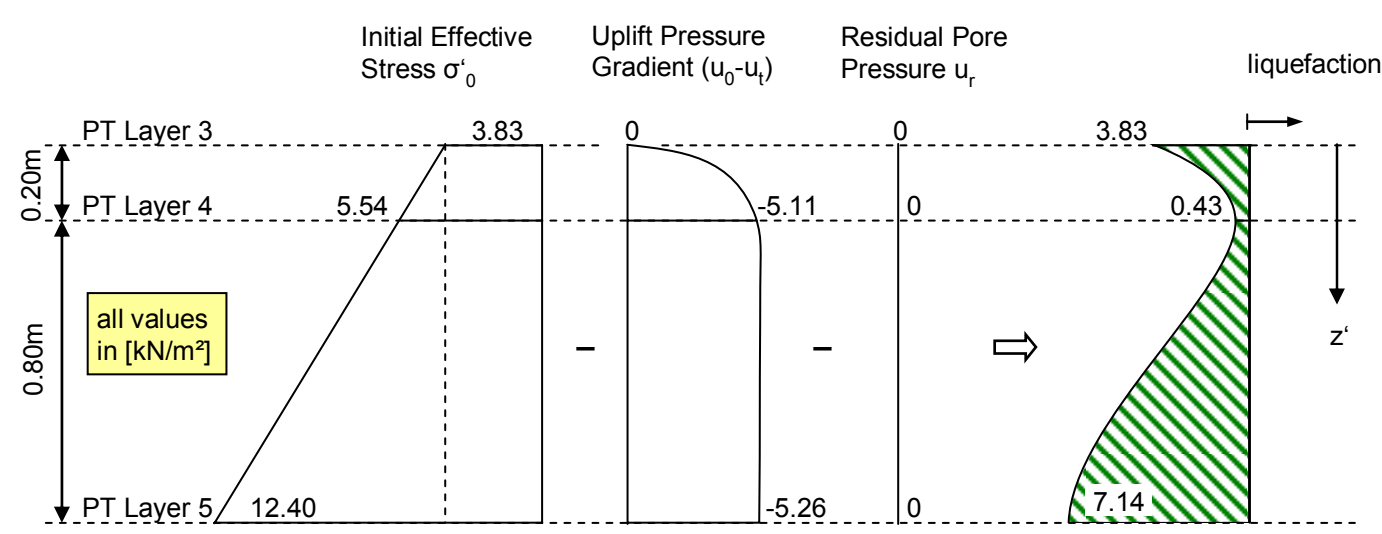

(b) No soil liquefaction for Model B at location B

Figure. 12. Comparative stability analysis for Model A and Model B under the same wave conditions (Test 09051802 with $\mathrm{H}=1.4 \mathrm{~m}, \mathrm{~T}=5 \mathrm{~s}, \mathrm{~h}=3.90 \mathrm{~m}$ )

\section{CONCLUDING REMARKS AND OUTLOOK}

The results of the hydraulic performance have shown that due to the high porosity of PBA revetment a lower defence structures with lower wave reflection might result as compared for instance to smooth impermeable revetments.

Regarding the response of the sand core beneath the revetment to both impact and non-impact load, the results show that the transient pore pressure in the upper sand layers may be crucial for the stability (transient soil liquefaction), if no sufficient burden resulting from the weight of both revetment and gravel underlayer is provided to generate the initial effective vertical stress required to resist against the upward directed pore pressure gradient.

Overall, the results have substantially contributed to improve the understanding of the physical processes involved in the wave-structure-foundation interaction. Nevertheless, further research is still needed to further improve the understanding and the prediction of the stepwise failure of the subsoil and to develop a coupled CFD-CSD model capable to describe (i) the wave field in front of the porous slope structure, the detailed external flow on, in and just beneath the revetment as well as the coupled internal flow in the underlying filter layer and sand core and (ii) the bending deformations and stresses in the revetment as well as the pore pressure and the effective stresses in the sand core beneath the revetment.

\section{ACKNOWLEDGMENTS}

The financial support of this study by BASF-Elastogran GmbH (since 2010 BASF-Polyurethanes $\mathrm{GmbH})$ is gratefully acknowledged. 


\section{REFERENCES}

Eurotop. 2007. European Overtopping Manual. Pullen, T.; Allsop, N.W.H.; Bruce, T.; Kortenhaus, A.; Schüttrumpf, H.; Van der Meer, J.W.; Kuratorium für Forschung im Küsteningenieurwesen: Die Küste, Heft 73, www.overtopping-manual.com.

Bijlsma, E. 2008. The Elastocoast system - A study of possible failure mechanisms. Delft University of Technology, Delft, The Netherlands, $159 \mathrm{p}$

Davidse, M.P. 2009. Experiment analysis; the relation between wave loading and resulting strain in an asphaltic concrete revetment. Master Thesis, Delft University of Technology, Faculty of Civil Engineering, Section Hydraulic Engineering, Delft, The Netherlands, 149 p.

Gu, D. 2007a. Hydraulic properties of PUR-revetments compared to those of open stone asphalt revetments. Delft University of Technology, Delft, The Netherlands, $153 \mathrm{pp}$.

Oumeraci, H., Kudella, M. and T. Staal. 2009a. Pre-design and preparatory works for the large-scale model tests on ELASTOCOAST revetment in GWK. Berichte Leichtweiß-Institut für Wasserbau, Technische Universität Braunschweig, Nr. 986, Braunschweig, Germany.

Oumeraci, H. and M. Muttray. 2001. Bemessungswellenparameter vor Strukturen mit verschiedenen Reflexionseigenschaften. Abschlussbericht DFG-Projekt, OU 1/3-3, Braunschweig, Germany, 93 p.(in German)

Oumeraci, H., Staal, T., Pfoertner, S., Ludwigs, G. and M. Kudella. 2009b. Hydraulic performance, wave loads and response of Elastocoast revetments and their foundation- A large scale model study. Final Report Berichte Leichtweiß-Institut für Wasserbau, Technische Universität Braunschweig, Nr. 988, Braunschweig, Germany, 176p + Annexes.

Pilarczyk, K.W., Klein Breteler, M. and A. Bezuijen. 1995. Wave forces and structural response of placed block revetments on inclined structures. In: Demirbilek, Z. and Kobayashi, N. (eds.): Wave forces on inclined and vertical structures, New York, USA, pp. 52-87.

Seelig, W.N. 1983. Wave reflection from coastal structures. Proceedings of Coastal Structures 1983, American Society of Civil Engineers (ASCE), pp. 961-973.

USACE 2002. Coastal Engineering Manual. E. M. Part-IV, 1110-2-1100, US Army Corps of Engineers, Washington D.C., USA .

Zanuttigh, B. and J.W. van der Meer. 2006. Wave reflection from coastal structures. Proceedings 30th International Conference Coastal Engineering (ICCE), ASCE, San Diego, USA, pp. 4337-4349. 